\title{
25 Research Square \\ Solar Radiation Limits the Use of Paddocks by Laying Hens Raised in the Free-range System
}

Evandro Menezes de Oliveira ( $\nabla$ zootecnista.evandro@gmail.com )

Federal Institute of Education, Science and Technology of Brasilia: Instituto Federal de Brasília - IFB https://orcid.org/0000-0002-0758-7401

\section{Larissa Queiroz Medeiros De Oliveira}

Technology and Science Institute of Brasilia

João Victor Do Nascimento Mós

University of Brasilia: Universidade de Brasilia

Bruno Emanoel Teixeira

University of Brasilia: Universidade de Brasilia

Sheila Tavares Nascimento

State University of Maring : Universidade Estadual de Maringa

\section{Research Article}

Keywords: Animal welfare, laying hens, natural behaviours, solar radiation

Posted Date: December 20th, 2021

DOI: https://doi.org/10.21203/rs.3.rs-1141332/v1

License: (c) (i) This work is licensed under a Creative Commons Attribution 4.0 International License.

Read Full License 


\section{Abstract}

Laying hens on the Free-range systems are susceptible to challenging situations in relation to the rearing environment. Therefore, this work evaluated how solar radiation influences the behaviour of laying hens raised in a Free-range system, in the Brazilian Savanna. The activities included data collection of meteorological variables and behavioural analysis of three-hundred commercial laying hens in relation to the frequency of use of indoor and outdoor areas of rearing housing. The solar radiation is the main factor that directly affects the heat gain of production animals, in this experiment had a high amplitude during all day, going from $33.42 \mathrm{~W} \mathrm{~m}^{-2}$, to $756.98 \mathrm{~W} \mathrm{~m}^{-2}$. It was observed that the highest frequency of $79 \%$ and $91 \%$ use of the barn areas by the hens was at $8 \mathrm{am}$ and $4 \mathrm{pm}$, respectively. The internal area of the housing was more used by hens $87 \%$ and $68 \%$ at $12 \mathrm{~h}$ and $14 \mathrm{~h}$, respectively. Hens were not observed in the paddocks at noon and $2 \mathrm{pm}$. Hens spend more than 6 hours of the day inside the housing to provide shelter from solar radiation. Which the conclusion the solar radiation influences the behaviour of laying hens, at times of the day of the higher incidence of radiation, and high air and global temperatures, it was not observed the presence of hens in the external areas of the housing, especially with the use of the paddocks, at these times the hens seek shelter inside the housing to get away from the incidence of direct solar radiation.

\section{Introduction}

The pressure of the population contributes for animal welfare rules to be applied in animal production systems (Molento, 2005; Ubabef, 2008; Gosling et al., 2014). Therefore, free-range systems are an alternative and a trend for raising animals such as laying hens and pigs, in order for the animals to be free to express their natural behaviours (Bestman, 2014; HFAC, 2018).

However, as the use of these systems differs in relation to temperate climate countries (as in European countries), and some concepts must be taken into consideration before their implementation in tropical climate countries, as is the case of Brazil. Being a continental country there are very distinct climatic characteristics, and most of its territory has high incidence of solar radiation and high air temperature (Da Silva and Maia, 2013).

The free-range system for laying hens brings the concept of opening the housing so that the hens have access to the outside area or are raised outdoors, to provide better welfare conditions (Yilmaz Dikmen et al., 2016; Gosling et al., 2014; HFAC, 2018), and meet the behavioural domain (Mellor and Beausoleil, 2015). However, despite providing the expression of natural behaviours such as wing flapping, scratching, perching, stretching, sand bathing among others (Bestman, 2014; Thimotheo, 2016; HFAC, 2018; Bartzike et al., 2019), which are not observed in the cage system, the meteorological factors directly affect the use of this system mainly by not providing favorable conditions related to thermal comfort (Mós et al., 2020).

For the laying poultry industry, the systems of raising hens in cages tend to decrease, but only removing hens from cages and opening the housing to external areas does not mean providing welfare for these 
animals. Based on this information, this work aimed to evaluate how solar radiation influences the behaviour of laying hens raised in a Free-range system, in the Brazilian Savanna.

\section{Materials And Methods}

The project "Environmental Education in research and animal production units" was registered with the Dean of Research and Innovation (PRPI) and Dean of Extension (PREX) in accordance with Resolution No. 024/2009 - RIFB. The research and rural extension project involved students from the Integrated and Subsequent Technical courses in Livestock and Higher Education in Agroecology, with the main theme "Environment and Animal Welfare".

The experiment was developed in the Experimental farm, of the Federal Institute of Education, Science and Technology of Brasilia - IFB, Planaltina campus, Federal District, Brazil. Located at Altitude 1080m, Latitude $15^{\circ} 66^{\prime} \mathrm{S}$ and Longitude $47^{\circ} 69^{\prime} \mathrm{W}$. The characteristic climate of the Federal District according to the KÖPPEN climate classification is high altitude tropical and is in the Aw zone (Alvares et al., 2013).

A total of 300 commercial free-range laying hens were observed, 150 laying hens of the GLK strain and 150 laying hens of the GLN strain, raised in a Free-range system. The activities included data collection of meteorological variables and behavioural analysis of laying hens regarding the frequency of use of the internal and external areas of the rearing housing.

\section{Meteorological variables}

The meteorological variables of relative humidity $(\mathrm{RH}, \%)$ and air temperature $\left(\mathrm{T}_{\mathrm{AIR}},{ }^{\circ} \mathrm{C}\right)$ were measured using a thermo-hygrometer (Protem2, Criffer). To measure the black globe temperature $\left(T_{B G},{ }^{\circ} \mathrm{C}\right)$, a black globe (Protem2, Criffer) was used, which is a hollow copper sphere, painted on the outside with black matte dye, with a diameter of $15 \mathrm{~cm}$, which were positioned in the sun and shade, and raised to the height of the hens (approximately $20 \mathrm{~cm}$ from the ground). Shortwave radiation $\left(R_{S}, W m-2\right)$ was measured by a photodiode from the meteorological station (Vaisala brand, model RWS200) of the Fazenda Água Limpa - FAL, of the Universidade de Brasília - UnB. The air speed ( $\left.A_{S}, m s-1\right)$ was measured using a digital propeller anemometer (TAN100, Incoterm). All these variables were measured simultaneously at 10minute intervals.

\section{Hens behaviour}

The behavioral observations were performed visually by two previously trained observers, equipped with clipboards, clock and pencil for the description of the ethogram (Table 1). The animals were observed from 08:00 am when the barn doors are opened to the housing, until 5:00 pm, when the hens enter the barn and doors are closed. Totaling 10 hours of observation during the day. The activity patterns of the animals were recorded every 20 minutes. The hens' preferred locations were observed, considered as free choice is described in the ethogram (Table 1), which was adapted according to the methodology described by Altmann (1974). 


\section{Statistical Analysis}

Data were analyzed by frequency analysis and chi-square with 0.10 probability error using the PROC FREQ procedure of SAS (Statistical Analysis System, version 9.2). Frequency analysis was performed according to the model:

$$
f_{r i}=\frac{f_{i}}{n}
$$

Where: $f_{r i}$ is the relative frequency of observed behaviour, according to the criteria in Table $3 ; f_{i}$ is the frequency of observed behaviour; $n$ is the total number of animals evaluated $(n=300)$. For the presentation of the results, the percentage relative frequency $\left(f_{r i} \%\right)$ for each behaviour was calculated by multiplying the results by 100 .

\section{Results}

\section{Meteorological variables}

The means of meteorological variables of shortwave radiation $\left(R_{S}, W m^{-2}\right)$, air temperature $\left(T_{A I R},{ }^{\circ} \mathrm{C}\right)$, black globe temperature in the sun and shade $\left(T_{B G},{ }^{\circ} \mathrm{C}\right)$, relative humidity $(R H, \%)$ and air speed $\left(A_{S}, \mathrm{~m} \mathrm{~s}^{-1}\right.$; Table 2).

Additionally, a survey was also done using data published in the Brazilian National Institute of Meteorology (INMET, 2020), of the maximum amount of incident shortwave radiation over the states of Brazil that make up the Brazilian Savanna, during all months of 2020 (Figure 2).

\section{Hens Behaviour}

The frequency of use of internal or external areas of the housing (paddock or shaded), were observed by the laying hens (Figure 1). At 8:00 am the distribution of hens was $79 \%$ in the paddock areas and $18 \%$ in the shaded area. The internal area of the housing was more used by the hens $87 \%$ and $68 \%$ at noon and $2 \mathrm{pm}$, respectively. At these same times $13 \%$ of the hens stayed in the external area with the presence of shade at $12 \mathrm{~h}$ and $32 \%$ at $14 \mathrm{~h}$. No hens were observed in the paddocks at noon and $2 \mathrm{pm}$. At $4 \mathrm{pm}$, the majority of the hens $91 \%$ returned to use the external area of the paddocks and shaded external area of the housing $8 \%$, while only $1 \%$ was in the internal area of the housing.

\section{Discussion}

The air temperature exceeded the annual average of Brasilia $25.9^{\circ} \mathrm{C}$ (INMET, 2020) with values above $27.30^{\circ} \mathrm{C}$ at $12 \mathrm{~h}$. On scalding days, air temperature ranged from 27 to $34.10^{\circ} \mathrm{C}$ (Table 2). The air temperature does not very much, with a temperature range of only $7^{\circ} \mathrm{C}$, which shows us that air temperature alone is not enough to define the level of stress that laying hens may be submitted throughout the day. 
Therefore, the importance of measuring the amount of shortwave radiation, which in the first hours of the day at 8 is around $33 \mathrm{~W} \mathrm{~m}^{-2}$ and peaked at $2 \mathrm{pm}$ with radiation of $756.98 \mathrm{~W} \mathrm{~m}^{-2}$ (Figure 1). The Sun emits the maximum value of shortwave radiation that reaches the planet Earth is around $1,350 \mathrm{~W} \mathrm{~m}^{-2}$, but the range that reaches the Earth's surface is around 800 to $1000 \mathrm{~W} \mathrm{~m}^{-2}$ at sea level (Da Silva, 2008). In this study this statement can be confirmed with the solar radiation survey, which showed that for all months of the year the shortwave radiation was above $700 \mathrm{~W} \mathrm{~m}^{-2}$ and that this situation worsens in the months of January, February, March, September, and November when the radiation exceeds $870 \mathrm{~W} \mathrm{~m}^{-2}$ (Figure 2).

The Brazilian Savanna (or Cerrado biomes) is located in the tropical zone and occupies the second largest Brazilian biomes with an extension of $2,036,448 \mathrm{~km}^{2}$ which is equivalent to occupying $23.9 \%$ of the national territory (Penereiro et al., 2018). Therefore, it becomes necessary to provide good environmental conditions for animals, considering that they can absorb heat from the environment, mainly by exposure to solar radiation and high air temperature (Maia et. al., 2020). These meteorological factors directly affect animals raised on pasture because it is a type of farming that does not provide favorable conditions related to thermal comfort (Mós et al., 2020).

Through the temperature of the black globe (in the sun and shade), we can establish the thermal sensation that the animal feels throughout the day. In this experiment, it ranged from 29.40 to $50.20 \mathrm{~W}$ $\mathrm{m}^{-2}$ with a range of $20.80 \mathrm{~W} \mathrm{~m}^{-2}$ with the globe in the sun, and between 28 to $38 \mathrm{~W} \mathrm{~m}^{-2}$ with a range of $10 \mathrm{~W} \mathrm{~m}^{-2}$ with the globe in the shade. This thermal sensation was what influenced the frequency of the hens' behaviour of staying inside or outside the rearing housing (Broom, 2010).

When relating solar radiation with the hens' behaviour, it was observed that the radiation is $33 \mathrm{~W} \mathrm{~m}^{-2}$ at 08:00am (Table 2), it was observed that the hens show greater dispersion over the paddocks and better use was made of the outside area of the housing, especially in the paddock using the pastures (Figure 1). Shortwave radiation, also known as solar radiation, is characterized as a heat gain mechanism for animals and surfaces exposed to the sun's rays (Da Silva, 2008; Da Silva and Maia, 2013; Gosling et al., 2014; Teixeira et al., 2021).

Regardless of the day evaluated, between $12 \mathrm{~h}$ and $14 \mathrm{~h}$ (Figure 1 ), times that the radiation reached 756.98 and black globe temperature at $50^{\circ} \mathrm{C}$, the laying hens remained inside the housing at the hottest times of the day, to protect themselves from the high incidence of solar radiation and high thermal sensation, for not finding shading areas (both natural and artificial) in the pen.

It was also observed that with and as the sun began to lower and form shade from the structure of the housing the hens at the exit door of the housing, that the hens began to crowd in the available shade strip, demonstrate the desire to leave the housing. When radiation begins to decrease at $4 \mathrm{pm}$ to 348.37 $\mathrm{W} \mathrm{m}{ }^{-2}$ on the hottest days (Table 2), consequently, the black globe temperature is lowered to $30.40^{\circ} \mathrm{C}$, is the time that all hens leave the housing toward the paddocks to use the pasture areas. 
It is important to note that by survival instinct, as the hens are animals considered "prey" and because they feel vulnerable when the pasture is higher than their size, they rarely use this area and do not go into dense vegetation. Just as was observed at $4 \mathrm{pm}$, where despite being loose outside the housing, most stayed outside the grass areas, so we should keep the grass trimmed at all times, in addition to the other regulations for grazing areas stipulated by Humane Farm Animal Care (HFAC, 2018).

However, it is remarkable how much direct interference solar radiation has on the Free-range system for laying hens. Between the period from 10 am to $4 \mathrm{pm}$ is 6 hours without any use of the hens to the paddocks, which shows the inefficiency of the purpose of this system since it is mandatory that the hens have access to the outdoor area for at least 6 hours of the day (HFAC, 2018). Therefore, it is necessary to provide shaded areas near the barn, either artificially, such as shading screens (Tainika and Şekeroğlu, 2021; Mós et al., 2021), or naturally, through the use of trees (Teixeira and Nascimento, 2020), so that the hens can use the outdoor area for longer and not suffer from direct radiation interference.

The same were cited in an article by Certified Humane Brazil, for the maintenance of productivity to hens and based on knowledge about physiology and animal behaviour one should always consider that they should have access to shade in the hottest periods of the day/year, even for species and breeds adapted to tropical regions (Cattani, 2020). Improving the environmental conditions meeting domain 2 of Animal Welfare (Mellor and Beausoleil, 2015), and consequently improve the health and quality of life of the hens.

The variations of solar radiation are direct, diffuse, and reflected radiation, which are subdivided according to their characteristics. The direct radiation is radiation that does not undergo mirroring as it travels to Earth, i.e., radiation descends in a straight line and directly reaches all surfaces. The diffuse radiation is caused by the deflection of direct solar radiation by some particles or molecules in the atmosphere, such as clouds, so that it reaches the ground at different angles. The reflected radiation is the radiation that reaches the ground and has a part of its energy reflected in other surfaces or animals (Da Silva, 2008; Da Silva and Maia, 2013).

Each radiation component interferes in different ways in poultry rearing systems. Only hens housed in fully enclosed and climate-controlled housings are free of shortwave radiation. Hens housed in conventional housings with open sides receive reflected radiation, and in the free-range system where hens have access to areas outside the housing, the hens are susceptible to all types of radiation, direct, diffuse, and reflected (Maia et al, 2020).

Letting the hens outdoors does not provide thermal comfort. Solar radiation, black globe temperature, and air temperature when they are above the hens' surface temperature are also considered additional sources of heat gain for the animal (Da Silva and Maia, 2013; Gosling et al, 2014; Teixeira et al., 2021). It is for this reason, that at the times of day with the highest incidence of radiation, and high air and shell temperatures, that the hens seek shelter inside the housing to get away from direct solar radiation. However, it is necessary to provide shading areas in the paddocks, and natural shade from trees is the 
most suitable in this situation, bringing the interaction of sustainable and durable systems (Teixeira and Nascimento, 2020).

\section{Conclusion}

Solar radiation influences the behaviour of laying hens, at times of day with a higher incidence of radiation, and high air and global temperatures, it was not observed the presence of hens in the external areas of the housing, especially with the use of the paddocks, at these times the hens seek shelter inside the housing to get away from the incidence of direct solar radiation.

\section{Declarations}

\section{Acknowledgments}

We would like to thank everyone on the support team for executing environmentally sustainable tasks. To the students of the Integrated Technical Course in Farming Integrated to High School, Subsequent Technical Course in Farming and Higher Education in Agroecology who participated in the data collection of hens observation and to the employees of the Experimental Research and Extension Units (UEP'S), of the Federal Institute of Education, Science and Technology of Brasilia - IFB, Planaltina campus, for the contribution for the work to be done. Evelyn Menezes de Oliveira, from the University of Brasília (UnB), revisited the linguistic.

\section{Ethics Declarations}

\section{Funding}

This work was supported by the Conselho Nacional de Desenvolvimento Científico e Técnico - CNPq.

\section{Conflicts of interest/Competing interests}

Not applicable. The authors declare no competing interests.

\section{Ethics approval}

The project "Environmental Education in research and animal production units" was registered with the Dean of Research and Innovation (PRPI) and Dean of Extension (PREX) in accordance with Resolution No. 024/2009 - RIFB. Federal Institute of Education, Science and Technology of Brasilia - IFB, Planaltina campus, Federal District, Brazil.

\section{Consent to participate}

Not applicable

\section{Consent for publication}


Not applicable

\section{Availability of data and material}

Not applicable

Code availability

Not applicable

\section{Authors' contributions}

EM, JV, LQ and BE conceived and designed the research. EM, JV, and BE data curation. EM, JV, and ST methodology and analytical tools. EM, LQ, and ST analyzed data. EM, LQ, JV, BE and ST wrote the manuscript. All authors read and approved the manuscript.

\section{Declaration of competing interest}

This manuscript has not been published elsewhere and is not under consideration by another journal.

\section{References}

1. Altmann, J. 1974. Observational study of behavior sampling methods. Behaviour, 49, 227-267.

2. Alvares C.A., Stape J.L., Sentelhas P.C., De Moraes Goncalves J.L., Sparovek G. 2013. Köppen's climate classification map for Brazil. Meteorologische Zeitschrift, 22(6):711-728.

3. Bartzike, G. B., Da Silva, E. A. S., Hirata, A. K., Nunes, K. C., Murakami, A. E. 2019. Bem-estar animal na produção de aves de postura: sistema Cage-Free. Anais do $2^{\text {a }}$ Semana Integrada de Zootecnia. Maringá, PR. 106-111.

4. Bestman, M. 2014. Managing Free-range Laying Hens. Low Input Breeds technical note. In: <http://www.lowinputbreeds.org/fileadmin/documents_organicresearch/lowinputbreeds/tn-4-5bestman-2014-free-range-hens.pdf>

5. Broom, D. M. 2010. Cognitive ability and awareness in domestic animals and decisions about obligations to animals. Applied Animal Behaviour Science 126, 1-11.

6. Cattani, P. R. 2020. CERTIFIED HUMANE BRASIL. In: <https://certifiedhumanebrasil.org/entendacomo-o-calor-influencia-no-bem-estar-animal-e-sua-produtividade/ >

7. Da Silva, R. G., Maia A. S. C. 2013. Basic physical mechanisms: Radiation. p.39-50. Em: Principles of animal Biometeorology. Springer, London, UK.

8. Da Silva, R.G. 2008. Radiação Solar. p.65-80. In: Biofísica ambiental: os animais e seu ambiente. Funep, Jaboticabal, SP.

9. Gosling, S. N., Bryce, E. K., Dixon, P. G., Gabriel, K. M., Gosling, E. Y., Hanes, J.M., Hondula, D. M., Liang, L., Mac Lean, P. A. B., Muthers, S., Nascimento S. T., Petralli, M., Vanos, J. K., Wanka, E. R. 2014. A 
glossary for biometeorology. International Journal of Biometeorology. 58(2):277-308.

10. HFAC. Humane Farm Animal Care, Referencial de Bem-estar Animal. 2018. Sistema de criação a pasto, free-range e caipira, colonial ou capoeira. p.13-16. Em: Padrões da HFAC para a produção de Galinhas Poedeiras. In: <http://materiais.certifiedhumanebrasil.org/agradecimento-normas-especiegalinhas-poedeiras.pdf >

11. INMET. Instituto Nacional de Meteorologia. 2020. In: <http://www.inmet.gov.br/portal/index.php? $r=b d m e p / b d m e p>$

12. Maia, A. S. C., Milan, H. F. M., Simão, B. R., Nascimento, C. C. N., Fonsêca, V. F. C. 2020. Fundamentos de transferência de calor aplicados a animais domésticos: Fisiologia térmica dos vertebrados. São Paulo: Cultura Acadêmica.

13. Mellor, D. J., Beausoleil, N. J. 2015. Extending the 'Five Domains' model for animal welfare assessment to incorporate positive welfare states. Animal Welfare. 24(3): 241-253.

14. Molento, C. F. M. 2005. Bem-estar e produção animal: aspectos econômicos - Revisão. Archives of Veterinary Science, 10(1):1-11.

15. Mós, J. V. N., Nascimento, S. T., Murata, L. S., Dos Santos, V. M., Steide Neto, A. J., De Oliveira, E. M., Lisboa, A. S., Silva, L. F. 2020. Thermal comfort of sows in free-range system in Brazilian Savanna. Journal of Thermal Biology. 88, 1-8.

16. Mós, J. V. N., Teixeira, B. E., Murata, L. S., Dos Santos, V. M., De Oliveira, E. M., Steidle Neto, A. J., Nascimento, S. T. 2021. Thermal comfort provided by different shading structures in free-range systems in Brazilian savanna. International Journal of Biometeorology. 1-10.

17. Penereiro, J. C., Badinger, A., Maccheri, N. A., \& Meschiatti, M. C. 2018. Distribuições de tendências sazonais de temperatura média e precipitação nos biomas brasileiros. Revista Brasileira de Meteorologia. 33(1): 97-113.

18. Tainika, B., Şekeroğlu, A. 2021. Environmental Enrichments in Laying Hen Production Systems with Emphasis on Welfare and Egg Quality. Turkish Journal of Agriculture-Food Science and Technology, 9(8):1398-1406.

19. Teixeira, B. E.; Nascimento, S. T. Avaliação Termográfica de Árvores do Cerrado. In: Anais do $26^{\circ}$ Congresso de iniciação Científica da Universidade de Brasília e 17º do Distrito Federal. 2020.

20. Teixeira, B. E.; De Oliveira, E.M.; Mós, J. V. N.; Nascimento, S. T.; Pereira, A. F. B.; Fonseca, L. R.; Toledo, J. B.; Santos, T. C. 2021. Termografia De infravermelho como ferramenta para estimar a transferência de calor sensível em codornas. In: Avesui, 2021, Evento Virtual. Anais do $5^{\circ}$. Congresso brasileiro de zootecnia de precisão e $19^{\circ}$. Seminário técnico científico de aves, suínos bovinos e peixes.

21. Thimotheo, M. 2016. Duração da qualidade de ovos estocados de poedeiras criadas no sistema "Cage-free". Dissertação (Mestrado) - Universidade Estadual Paulista (UNESP), Faculdade de Ciências Agrárias e Veterinárias. Jaboticabal, SP. 55.

22. UBABEF - União Brasileira de Avicultura. 2008. Protocolo de Bem-estar para aves poedeiras. In: <http://www.avisite.com.br/legislacao/anexos/protocolo_de_bem_estar_para_aves_poedeiras.pdf >. 
23. Yilmaz Dikemen, B.; Ípek, A.; Sahan, Ü.; Petek, M. E Sözcu, A. 2016. Egg production and welfare of laying hens kept in diferent housing system (conventional, enriched cage and Free-range). Poultry Science. 95(7):1564-1572.

\section{Tables}

Table 1 The behaviour of laying in relation to the places where the hens stay, which can be areas of the paddocks, shaded areas and the internal area of the housing

\begin{tabular}{|ll|}
\hline Behaviour & Local \\
\hline Preference of hens & Areas of paddocks \\
\cline { 2 - 2 } & Shaded áreas \\
& Indoors area of the housing \\
\hline
\end{tabular}

Table 2 Maximum values of meteorological variables of shortwave radiation $\left(R_{S}, W m^{-2}\right)$, air temperature $\left(T_{A I R}{ }^{\circ} \mathrm{C}\right)$, black globe temperature in the sun and shade $\left(T_{B G},{ }^{\circ} \mathrm{C}\right)$, relative humidity $(R H, \%)$ and air speed $\left(A_{S}, \mathrm{~m} \mathrm{~s}^{-1}\right)$, measured in the Brazilian Savanna, from 8 am to $16 \mathrm{pm}$.

\begin{tabular}{|lllll|}
\hline Meteorological & \multicolumn{3}{l}{ Daylight hours } \\
\cline { 2 - 5 } & $08 \mathrm{~h}$ & $12 \mathrm{~h}$ & $14 \mathrm{~h}$ & $16 \mathrm{~h}$ \\
\hline Shortwave radiation $\left(\mathrm{W} \mathrm{m}^{-2}\right)$ & 33.42 & 598.98 & 756.98 & 348.37 \\
\hline Air temperature $\left({ }^{\circ} \mathrm{C}\right)$ & 27.30 & 29.80 & 34.10 & 28.70 \\
\hline Black globe temperature at sun $\left({ }^{\circ} \mathrm{C}\right)$ & 29.40 & 42.30 & 50.20 & 30.25 \\
\hline Black globe temperature at shade $\left({ }^{\circ} \mathrm{C}\right)$ & 28.00 & 33.10 & 38.00 & 29.60 \\
\hline Relative humidity $(\%)$ & 75 & 63 & 58 & 59 \\
\hline Air speed $\left(\mathrm{m} \mathrm{s}^{-1}\right)$ & 1 & 0.6 & 0.8 & 0.6 \\
\hline
\end{tabular}

Table 3 is not available with this version.

\section{Figures}




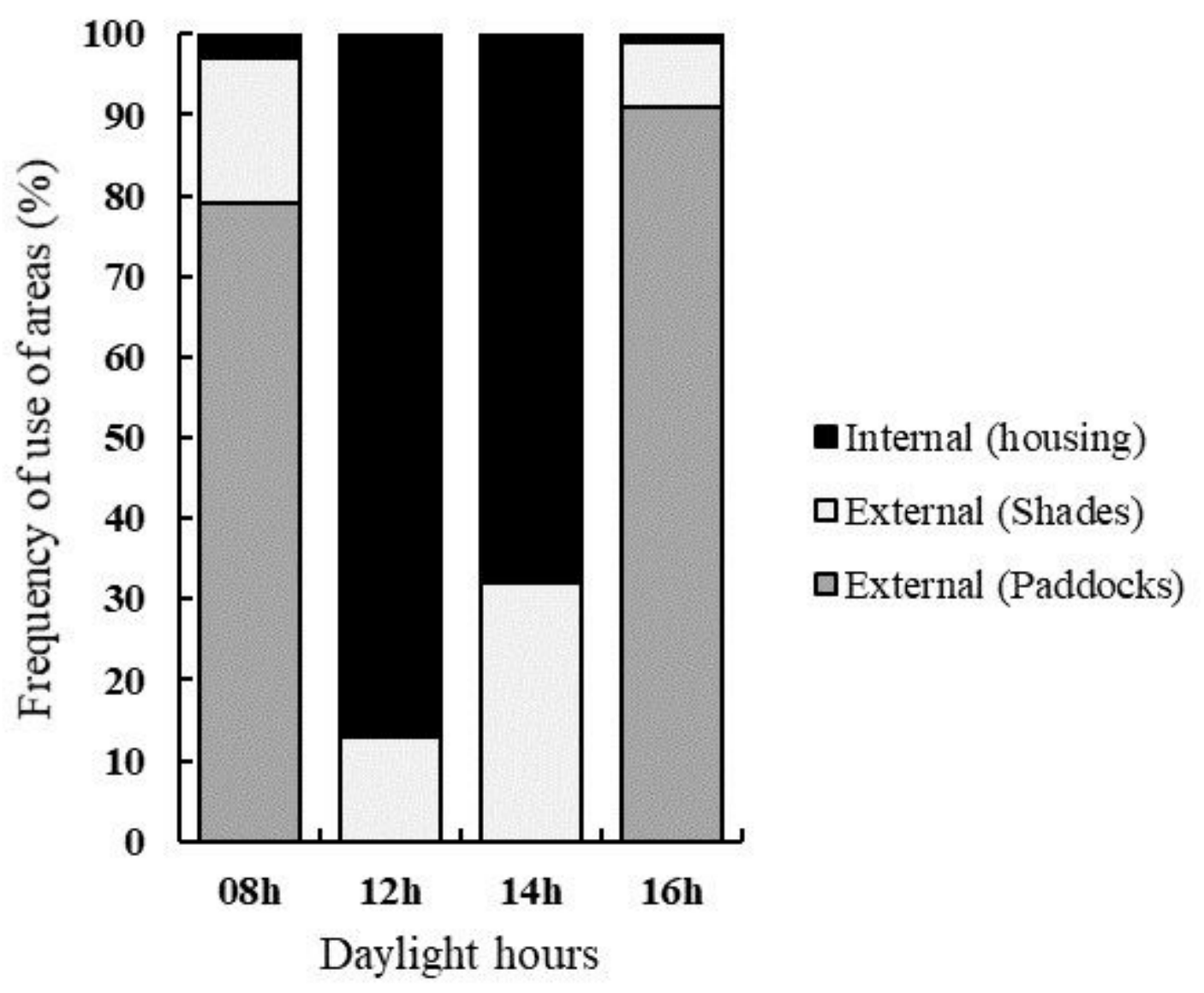

Figure 1

Frequency of use of access areas (internal and external to the housing) by Free-range laying hens on the Brazilian Savanna. 


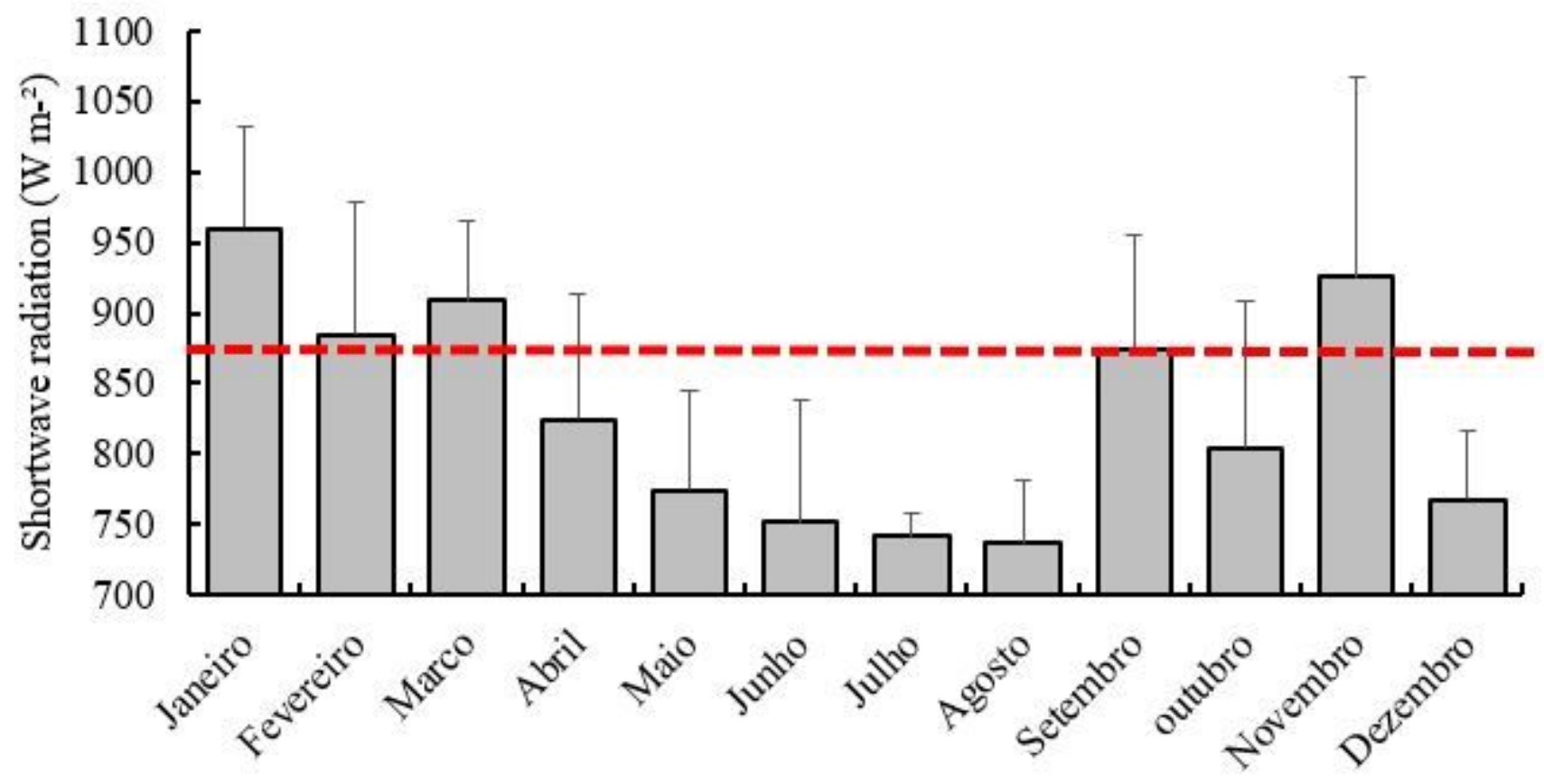

Figure 2

Means of shortwave radiation ( $\mathrm{RS}, \mathrm{W} \mathrm{m}^{-2}$ ) during all months of a year in the Brazilian Savanna states. Source: adapted from INMET - National Institute of Meteorology. 